\title{
Phytoprotection
}

\section{Parasitism of spores of the vesicular-arbuscular mycorrhizal fungus, Glomus dimorphicum}

\section{S.M. Boyetchko et J.P. Tewari}

Volume 72, numéro 1, 1991

URI : https://id.erudit.org/iderudit/706000ar

DOI : https://doi.org/10.7202/706000ar

Aller au sommaire du numéro

Éditeur(s)

Société de protection des plantes du Québec (SPPQ)l

ISSN

0031-9511 (imprimé)

1710-1603 (numérique)

Découvrir la revue

Citer cet article

Boyetchko, S. \& Tewari, J. (1991). Parasitism of spores of the vesicular-arbuscular mycorrhizal fungus, Glomus dimorphicum. Phytoprotection, 72(1), 27-32. https://doi.org/10.7202/706000ar
Résumé de l'article

Nous avons examiné des spores parasitées du Glomus dimorphicum. Les microscopies photonique et électronique ont révélé des perforations d'environ 0,25 à $1,0 \mu \mathrm{m}$ de diamètre dans la paroi de la spore. La présence de papilles, réponse dynamique de l'hôte, suggère que le parasitisme se produit pendant que le champignon mycorhizien à vésicule et arbuscule est encore vivant. Aucune structure filamenteuse n'a été détectée dans les spores; cependant, des kystes d'organismes ressemblant à des amibes ont été trouvés dans les spores et ont aussi été observés en milieu gélose sur lequel ont été placées des spores du G. dimorphicum stérilisées en surface mais contenant de tels organismes. Il est postulé qu'un organisme ressemblant à une amibe était le parasite, puisque les perforations de la paroi de la spore étaient minuscules et qu'aucun champignon ou bactérie n'a été détecté dans les spores. 


\title{
Parasitism of spores of the vesicular-arbuscular mycorrhizal fungus, Glomus dimorphicum
}

\author{
S.M. Boyetchko and J.P. Tewari \\ Department of Plant Science, University of Alberta, \\ Edmonton, Alberta, Canada T6G $2 P 5$
}

(Received 1990-12-17; accepted 1991-03-26)

Spores of Glomus dimorphicum were examined for parasitism. Light and scanning electron microscopy revealed perforations, approximately 0.25 to $1.0 \mu \mathrm{m}$ in diameter, in the spore wall. The presence of papillae, a dynamic host response, suggested that the parasitism occurred while the vesicular-arbuscular mycorrhizal fungus was still alive. No filamentous structures were detected in the spores; however, cysts of amoeba-like organisms were found in the spores and were also observed on agar plates on which surface-sterilized spores of $G$. dimorphicum containing such organisms were placed. It is postulated that an amoeba-like organism was the parasite, since the perforations on the spore wall were minute and no bacteria or fungi were seen inside the spores.

Boyetchko, S.M., and J.P. Tewari. 1991. Parasitism of spores of the vesicular-arbuscular mycorrhizal fungus, Glomus dimorphicum. PHYTOPROTECTION 72: 27-32.

Nous avons examiné des spores parasitées du Glomus dimorphicum. Les microscopies photonique et électronique ont révélé des perforations d'environ 0,25 à $1,0 \mu \mathrm{m}$ de diamètre dans la paroi de la spore. La présence de papilles, réponse dynamique de l'hôte, suggère que le parasitisme se produit pendant que le champignon mycorhizien à vésicule et arbuscule est encore vivant. Aucune structure filamenteuse n'a été détectée dans les spores; cependant, des kystes d'organismes ressemblant à des amibes ont été trouvés dans les spores et ont aussi été observés en milieu gélosé sur lequel ont été placées des spores du G. dimorphicum stérilisées en surface mais contenant de tels organismes. Il est postulé qu'un organisme ressemblant à une amibe était le parasite, puisque les perforations de la paroi de la spore étaient minuscules et qu'aucun champignon ou bactérie n'a été détecté dans les spores.

\section{Introduction}

Parasitism of vesicular-arbuscular (VA) mycorrhizal fungi has been documented (Daniels and Menge 1980; Paulitz and Menge 1984, 1986; Ross and Daniels 1982; Sylvia and Schenck 1983) but such studies are few and its importance in the ecology of VA mycorrhizal fungi is often underrated. The germination of parasitized spores of VA mycorrhizal fungi may be inhibited (Sylvia and Schenck 1983) and survival of these fungi in the field may be reduced (Paulitz and Menge 1984). The activity of such parasites may affect experimental results and may prevent successful large scale culture of pure VA mycorrhizal fungi (Daniels and Menge 1980; Ross and Daniels 1982). Paulitz and Menge (1986) reported that the parasite Anguillospora pseudolongissima Ranzoni reduced the inoculum potential of Glomus deserticola Trappe, Bloss and Menge. Results showed that root colonization by the VA mycorrhizal fungus and growth response of

$\overline{0031-9511 / 91 \$ 1.00+.10}$ onions was reduced due to the effect of the parasite on mycorrhizal spores when the spore density was low.

The most frequently observed parasites of VA mycorrhizal spores are Spizellomyces Barr, Rhizidiomycopsis Sparrow, and a Pythium-like fungus (Barr 1980; Hetrick 1984; Paulitz and Menge 1984; Ross and Ruttencutter 1977; Schenck and Nicolson 1977; Sparrow 1977). The Pythium-like fungus parasitized VA mycorrhizal fungi inside the root. The chytrideaceous fungi were observed to encyst on the fungal spore wall, germinate, and penetrate the spore (Sparrow 1977). Daniels and Menge (1980) isolated hyphomycetous parasites (A.pseudolongissima and Humicola fuscoatra Traaen) and Sylvia and Schenck (1983) observed species of Fusarium Link ex Fr., Penicillium Link ex Fr., Trichoderma Pers. ex Fr., and Chaetomium Kunze ex Fr. contaminating chlamydospores of three Glomus Tul. and Tul. species. Spindle cells of Labyrinthula Cienk. have also been isolated from the spores of Gigaspora gigantea (Nicol. and Gerd.) Gerd. and Trappe (Koske 1981). Perforations of soil-borne 
spores of some phytopathogenic fungi by mycophagous amoebae have been documented (Anderson and Patrick 1978) and studies have shown amoebae to be associated with VA mycorrhizal spores as well (Coley et al. 1978).

Varied susceptibility of VA mycorrhizal fungi to parasites has been suggested. Glomus macrocarpum Gerd. and Trappe was observed to be more susceptible to parasitism than Gigaspora gigantea (Ross and Ruttencutter 1977) and species of VA mycorrhizal fungi producing heavily melanized spores appeared to be more resistant to parasites than those producing hyaline spores (Daniels and Menge 1980; Hetrick 1984). This suggests that mature spores, which are often melanized, may be able to survive better in soil than the young, hyaline spores.

The objective of this study was to document the symptoms and signs associated with parasitism of the spores of Glomus dimorphicum Boyetchko and Tewari. This VA mycorrhizal fungus was described from this laboratory and is being studied from various perspectives (Boyetchko and Tewari 1986, 1990). The term parasitism, instead of hyperparasitism used by some authors (Bhattacharjee et al. 1982; Daniels and Menge 1980; Lee and Koske 1990; Ross and Daniels 1982), is deliberately used in this paper. The latter term is deemed inappropriate as the VA mycorrhizal fungi are generally not parasites (Bagyaraj 1984).

\section{Materials and methods}

Large single chlamydospores of $G$. dimorphicum were isolated from soil collected from Neerlandia, Alberta (latitude $54^{\circ} 25^{\prime}$ and longitude $114^{\circ} 20^{\prime}$ ) by wet-sieving and decanting (Gerdemann and Nicolson 1963) and collected onto filter paper under suction. Spores were observed by light microscopy and scanning electron microscopy (SEM). Spores examined by light microscopy were mounted onto slides in lactophenol. Spores for SEM were vapor-fixed with osmium tetroxide overnight, mounted onto stubs, airdried and coated with gold. Some of the spores were fractured with a dissecting needle before coating with gold to allow the interior of the spores to be observed. The spores were observed in a Cambridge Stereoscan 150 SEM.
In order to isolate parasites of $G$. dimorphicum, the spores were surface sterilized in $0.5 \%$ sodium hypochlorite for $20 \mathrm{~s}$, washed with sterile distilled water and placed onto hay-infusion agar plates. The hay-infusion agar plates were prepared by boiling $50 \mathrm{~g}$ dry hay in $1 \mathrm{~L}$ of distilled water for $1 \mathrm{~h}$, filtering the hay from the extract and adding $20 \mathrm{~g}$ agar. The hay-extract with agar was then steamsterilized in an autoclave and poured into petri plates. The presumed parasites isolated were observed by light microscopy.

\section{Results and discussion}

Light microscopy revealed transverse striations in the walls of the mature spores of $G$. dimorphicum (Fig. 1), similar to those found in the walls of Gigaspora candida Bhatt., Muker., Tewar., and Skoropad (Bhattacharjee et al. 1982). These structures were not part of the normal wall as determined by SEM (Fig. 2 ). The perforations were dispersed singly, continued through the wall, and ranged from 0.25 to $1.0 \mu \mathrm{m}$ in diameter. The outlines of the perforations were even or jagged (Figs. 3, 4). One annulate perforation was also observed (Fig. 5).

The identity of the organisms causing these perforations is uncertain. These organisms are not filamentous as no such structures were observed in or on these spores (Figs. 2, 3, 4, 7, $11,12)$. Perforations and annulations have been observed on spores of Gigaspora candida, Cochliobolus sativus (Ito and Kurib.) Drechs. ex Dastur, Thielaviopsis basicola (Berk. and Br.) Ferraris, and Gaeumannomyces graminis (Sacc.) v. Arx and Olivier (Anderson and Patrick 1978; Bhattacharjee et al. 1982; Cook 1982). Mycophagous vampyrellid amoebae are known to cause such perforations and annulations, including minute holes (Anderson and Patrick 1978, 1980). Old and Patrick (1976) had earlier suggested that such perforations could be caused by soil bacteria which agglutinate to the spore surfaces of $C$. sativus and $T$. basicola by secreting the bridging polymers and subsequently enzymatically creating the perforations. Similar conclusions were reached by Old and Wong (1976). While the evidence is overwhelming that these minute perforations are caused by soil microbiota (Old and Patrick 1976), conclusive proof of pathogenicity and 

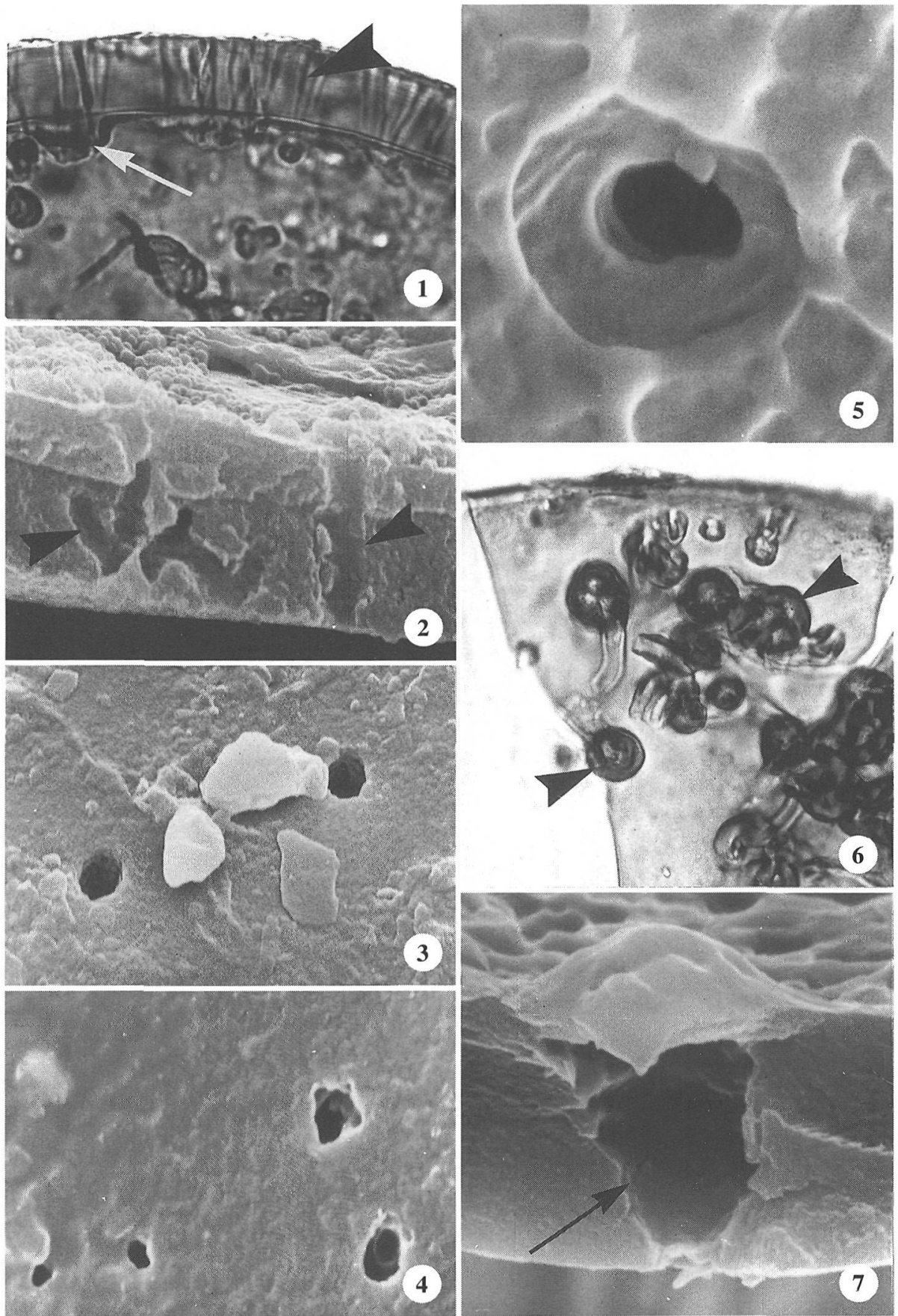

\section{Figure 1-7.}

Glomus dimorphicum. Spores showing symptoms of parasitism. Figure 1. Light microphotograph showing transverse striations (arrowhead) and a hemispherical papilla (arrow) in the spore wall. X 650. Figure 2. SEM photograph illustrating the perforations (arrowheads) transversing the spore wall. Note the absence of any filamentous structures on the inside of the spore. X 6000 . Figure 3. Perforations on the outer spore wall surface. X 5 500. Figure 4. Various sizes of perforations with even and jagged outlines. X 6000 . Figure 5. Enlarged view of an annulate-type perforation. X 14000 . Figure 6. Light microphotograph showing papillae (arrowheads). X 650. Figure 7. SEM photograph showing a perforation through the spore wall (arrow) and formation of a papilla. X 6750. 


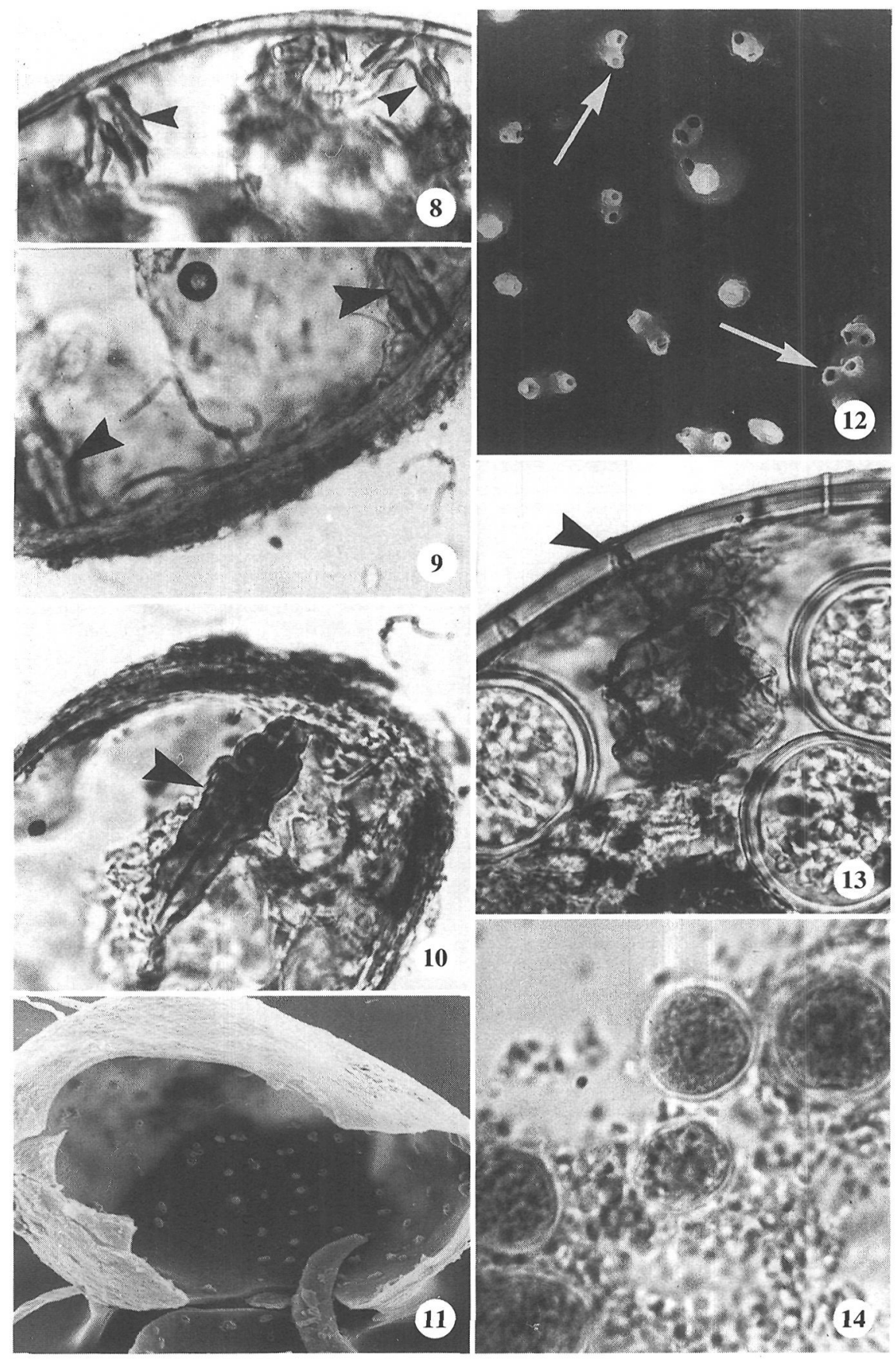

Figure 8-14.

Glomus dimorphicum. Spores showing symptoms and possible signs of parasitism. Figure 8. Light microphotograph showing hyaline, elongate papillae (arrowheads). X 500. Figures 9, 10. Light microphotographs illustrating brownish-colored, elongate papillae (arrowheads). Fig. 9, X 600; Fig. 10, X 550. Figures 11, 12. SEM photographs showing many papillae viewed from the inside of the spore. Note the perforations through the papillae (arrows). Fig. 11, X 300; Fig. 12, X 1200 . Figure 13. Light microphotograph showing thick-walled cysts inside the spore. Also, note the transverse striations in the wall (arrowhead). X 600. Figure 14. Cysts of amoeba-like organisms from a culture grown on hayinfusion agar and stained with lactophenol cotton-blue. Cells of a yeast-like contaminant are dispersed around the cysts. $X 750$. 
data on isolation of the responsible microbiota are still lacking.

Both light microscopy and SEM revealed many spores exhibiting reaction zones in the form of papillae (Figs. 1, 6-12). The papillae ranged from hyaline to brownish-colored and from hemispherical to elongated structures. One to a few perforations traversed through each papilla (Figs. 11,12). Papillae are host cell wall thickenings developed in response to invasion by parasites and represent a dynamic host defense response to infection. The formation of papillae as a host response to infection has been documented in vascular plants and in mycoparasitic relationships (Akutsu et al . 1980; Edwards and Allen 1970; Tsuneda et al. 1976). The present study suggests that the spores of $G$. dimorphicum were parasitized while they were still viable. A passing mention of "internal projections" in spores of Sclerocystis sinuosa Gerdemann and Bakshi "probably formed in response to parasitic attack by other soil microorganisms" was made earlier (Gerdemann and Bakshi 1976). Inward projections in the cell walls of a few other VA mycorrhizal fungi have also been noticed (Gerdemann and Trappe 1974; Iqbal and Perveen 1980). Lee and Koske (1990) have recorded similar structures (referred to as lignituber-like structures) in the younger parasitized spores of $G$. gigantea.

Much of the literature describing parasitism of VA mycorrhizal fungi does not provide evidence as to whether the spores were viable or dead when attacked by microbes (Daniels and Menge 1980; Ross and Ruttencutter 1977; Schenck and Nicolson 1977; Sparrow 1977). Spizellomyces punctatum (Koch) Barr (=Phlyctochytrium punctatum Koch), a fungus found on spores of some VA mycorrhizal fungi and believed to be a parasite, was shown to parasitize non-viable spores of Gigaspora margarita Becker and Hall (Paulitz and Menge 1984). The evidence showed that $S$. punctatum is primarily a saprophyte but the possibility that the fungus may also be a weak parasite was not ruled out. Lee and Koske (1990) studied parasitized spores of $G$. gigantea in different stages of health and showed that lignituber-like structures were formed in younger spores while fine radial canals were formed in heat-killed spores.
It has been suggested that highly melanized mycorrhizal spores are resistant to parasitism and that light-colored spores of mycorrhizal species are more susceptible (Daniels and Menge 1980; Hetrick 1984). However, Anderson and Patrick (1978) observed the selective feeding of amoebae on pigmented spores of C. sativus and T. basicola. From the present study, it appeared that the mature, dark-colored spores are parasitized more than the younger spores, but when the spores became parasitized is uncertain. Young single spores of $G$. dimorphicum containing the outer hyaline wall layer, characteristic of this species (Boyetchko and Tewari 1986), have not revealed extensive parasitism. The outer wall layer could very well serve as a means of protecting the spore from parasitism before it eventually sloughs off.

Most spores of $G$. dimorphicum that showed symptoms of parasitism in the form of perforations, papillae, etc., had no signs of the parasites that could be identified. In some cases, irregular aggregates of material were observed by SEM inside the spores (Figs. 2, 7) but it was unclear whether these were masses of spore cytoplasm or perhaps amoebae. Light microscopy revealed spherical, thick-walled colorless structures containing irregular bodies inside some of the mycorrhizal spores (Fig. 13). Hay-infusion agar plates, containing surface-sterilized spores of $G$. dimorphicum, produced cultures of amoebalike organisms that encysted to produce structures similar to those observed inside the spores (Fig. 14). Therefore, the spherical bodies inside the spores of $G$. dimorphicum may be cysts of amoeba-like organisms. Agricultural soils are rich in mycophagous amoebae as indicated by the work of Anderson and Patrick (1978) and Duczek (1983). Further studies are needed to characterize the amoeboid parasites.

There are problems in satisfying Koch's postulates with parasites of VA mycorrhizal fungi. Such studies with other fungi are carried out in dual cultures of parasites and their hosts. The VA mycorrhizal fungi are obligate symbionts which, to date, have not been grown in pure culture. For this reason, it has so far not been possible to use the traditional Koch's postulates approach in the case of VA mycorrhizal fungi. However, there is at least one 
possibility open for future studies. Clean spores of VA mycorrhizal fungi could be raised in pot cultures, extracted, placed with the parasite in a sterile medium (e.g. sand) and satisfying Koch's postulates attempted. Pot cultures of VA mycorrhizal fungi almost always get contaminated with secondary invaders and such experiments cannot be rigidly controlled. Another approach to ascertain the involvement of amoebae could be through the use of amoebicidal chemicals in pot cultures.

Special thanks are extended to Mr. George Braybrook for his help on SEM. This research was supported through grants from Agriculture Canada and Alberta Agricultural Research Trust to J.P. Tewari. Award of a graduate fellowship to S.M. Boyetchko from the Canadian Wheat Board is also gratefully acknowledged.

Akutsu, K., Y. Doi, and K. Yora. 1980. Elemental analysis of papillae and cytoplasmic vesicles formed at the penetration site by Erysiphe graminis f.sp. hordei in epidermal cells of barley leaves. Ann. Phytopathol. Soc. Jpn. 46: 667-671.

Anderson, T. R., and Z. A. Patrick. 1978. Mycophagous amoeboid organisms from soil that perforate spores of Thielaviopsis basicola and Cochliobolus sativus. Phytopathology 68: 1618-1626.

Anderson, T.R., and Z.A. Patrick. 1980. Soil vampyrellid amoebae that cause small perforations in conidia of Cochliobolus sativus. Soil Biol. Biochem. 12: 159-167.

Bagyaraj, D.J. 1984. Biological interactions with VA mycorrhizal fungi. Pages 131-153 in C.L. Powell and D.J. Bagyaraj (eds.). VA Mycorrhiza. CRC Press Inc., Boca Raton, Florida

Barr, D.J.S. 1980. An outline for the reclassification of the Chytridiales, and for a new order, the Spizellomycetales. Can. J. Bot. 58:2380-2394.

Bhattacharjee, M., K.G. Mukerji, J.P. Tewari, and W.P.Skoropad. 1982. Structure and hyperparasitism of a new species of Gigaspora. Trans. Br. Mycol. Soc. 78: 184-188.

Boyetchko, S.M., and J.P. Tewari. 1986. A new species of Glomus (Endogonaceae, Zygomycotina) mycorrhizal with barley in Alberta. Can. J. Bot. 64:9095.

Boyetchko, S.M., and J.P. Tewari. 1990. Root colonization of different hosts by the vesicular-arbuscular mycorrhizal fungus Glomus dimorphicum. Plant Soil 129: $131-136$

Coley, S.C., K.L. Baker, G.R. Hooper, and G.R. Safir. 1978. Spore wall development of the endomycorrhizal fungi Glomus fasciculatum and Glomus mosseae and a possible association with an amoeboid species. Proc. Am. Phytopathol. Soc. 12: 392 (Abstract).

Cook, R.J. 1982. Progress toward biological control of plant pathogens, with special reference to take-all of wheat. Agric. For. Bull., Univ. Alta. 5: 22-30.

Daniels B.A., and J.A. Menge. 1980. Hyperparasitization of vesicular-arbuscular mycorrhizal fungi. Phytopathology 70: 584-588.
Duczek, L.J. 1983. Populations of mycophagous amoebae in Saskatchewan soils. Plant Dis. 67: 606-608.

Edwards, H.H., and P.J. Allen. 1970. A fine structure study of the primary infection process during infection of barley by Erysiphe graminis f.sp. hordei. Phytopathology 60: 1504-1509.

Gerdemann, J.W., and B.K. Bakshi. 1976. Endogonaceae of India: Two new species. Trans. Br. Mycol. Soc. 66: 340-343.

Gerdemann, J.W., and T.H. Nicolson. 1963. Spores of mycorrhizal Endogone species extracted from soil by wet sieving and decanting. Trans. Br. Mycol. Soc. 46: 235-2.44.

Gerdemann, J.W., and J. Trappe. 1974. The Endogonaceae of the Pacific Northwest. Mycologia Memoir No. 5, 76 pp.

Hetrick, B.A.D. 1984. Ecology of VA mycorrhizal fungi. Pages 35-55 in C.L. Powell and D.J. Bagyaraj (eds.). VA Mycorrhiza. CRC Press Inc., Boca Raton, Florida.

Iqbal, S.H., and B. Perveen. 1980. Some species of Sclerocystis (Endogonaceae) from Pakistan. Trans. Mycol.Soc. Jpn. 21:57-63.

Koske, R.E. 1981. Labyrinthula inside the spores of a vesicular-arbuscular mycorrhizal fungus. Mycologia 73: 1175-1.180.

Lee, P., and R.E. Koske. 1990. Hyperparasites and associated microorganisms of Gigaspora gigantea in a sand dune. 8th North American Conference on Mycorrhizae. Jackson, Wyoming,p. 180 (Abstract).

Old, K.M., and Z.A. Patrick. 1976. Perforation and lysis of spores of Cochliobolus sativus and Thielaviopsis basicola in natural soils. Can. J. Bot. 54:27982809.

Old, K.M., and J.N.F. Wong. 1976. Perforation and lysis of fungal spores in natural soils. Soil Biol. Biochem. 8: 285-292.

Paulitz, T.C., and J.A. Menge. 1984. Is Spizellomyces punctatum a parasite or saprophyte of vesicular-arbuscular mycorrhizal fungi? Mycologia 76: 99-107.

Paulitz, T.C., and J.A. Menge. 1986. The effects of a mycoparasite on the mycorrhizal fungus, Glomus deserticola. Phytopathology 76:351-354.

Ross, J.P., and B.A. Daniels. 1982. Hyperparasitism of endomycorrhizal fungi. Pages 55-58 in N.C. Schenck (ed.). Methods and principles of mycorrhizal research. Am. Phytopathol. Soc., St. Paul, Minnesota.

Ross, J.P., and R. Ruttencutter. 1977. Population dynamics of two vesicular-arbuscular endomycorrhizal fungi and the role of hyperparasitic fungi. Phytopathology 67: 490-496.

Schenck, N.C., and T.H. Nicolson. 197'7. A zoosporic fungus occurring on species of Gigaspora margarita and other vesicular-arbuscular mycorrhizal fungi. Mycologia 69: 1049-1053.

Sparrow,F.K.1977.A Rhizidiomycopsis on azygospores of Gigaspora margarita. Mycologia 69: 1053-1058.

Sylvia, D.M., and N.C. Schenck. 1983. Germination of chlamydospores of three Glomus species as affected by soil matric potential and fungal contamination. Mycologia 75:30-35.

Tsuneda, A., W.P.Skoropad, and J.P. Tewari. 1976. Mode of parasitism of Alternaria brassicae by $\mathrm{NeC}$ tria inventa. Phytopathology 66: 1056-1064. 